\title{
Extracellular Acidity Potentiates AMPA Receptor-Mediated Cortical Neuronal Death
}

\author{
John W. McDonald, Tim Bhattacharyya, Stefano L. Sensi, Doug Lobner, Howard S. Ying, \\ Lorella M.T. Canzoniero, and Dennis W. Choi \\ Center for the Study of Nervous System Injury and Department of Neurology, Washington University School of Medicine, \\ St. Louis, Missouri 63110
}

The extracellular acidity that accompanies brain hypoxia-ischemia is known to reduce both NMDA and AMPA-kainate receptor-mediated currents and NMDA receptor-mediated neurotoxicity. Although a protective effect of acidic $\mathrm{pH}$ on AMPAkainate receptor-mediated excitotoxicity has been assumed, such has not been demonstrated. Paradoxically, we found that lowering extracellular $\mathrm{pH}$ selectively increased AMPA-kainate receptor-mediated neurotoxicity in neocortical cell cultures, despite reducing peak elevations in intracellular free $\mathrm{Ca}^{2+}$. This injury potentiation may, at least in part, be related to a slowed

Excitotoxic glutamate receptor overactivation likely contributes to the neuronal death induced by brain hypoxia-ischemia (Meldrum, 1985; Rothman and Olney, 1987; Choi, 1988). NMDA-type glutamate receptors appear to play a prominent role in mediating this neuronal death (Simon et al., 1984; Albers et al., 1992), likely reflecting their special ability to mediate rapid $\mathrm{Ca}^{2+}$ influx leading to cellular $\mathrm{Ca}^{2+}$ overload (MacDermott et al., 1986; Choi, 1992). However, pharmacological blockade of AMPA-kainatetype glutamate receptors also produces substantial protective effects in the ischemic brain. Neuroprotective efficacy has been demonstrated in both global ischemia (Sheardown et al., 1990, 1993; Balchen and Diemer, 1992; Le-Peillet et al., 1992; Pellegrini-Giampietro et al., 1992; for review, see Gill, 1994) and focal ischemia (Buchan et al., 1991a; Smith and Meldrum, 1992) models. The most striking observations are the ability of AMPA antagonists to reduce neuronal loss in the CA1 hippocampal subfield, cortex, striatum, and cerebellum after global ischemia, a setting where NMDA antagonists are relatively ineffective (Sheardown et al., 1990; Buchan et al., 1991b). However, the possibility has been raised that the dramatic protection provided by delayed treatment with AMPA-kainate receptor antagonists observed in early studies may have been attributable in part to drug-induced brain hypothermia (Nurse and Corbett, 1996).

The prominent role of AMPA-kainate receptor-mediated injury in animal models of ischemia contrasts with the low profile role of AMPA-kainate receptor-mediated injury found in several in vitro models of excitotoxicity (Choi, 1992). In mouse cortical cell cultures, AMPA-kainate antagonists do not increase neuro-

Received Sept. 8, 1998; revised April 23, 1998; accepted May 28, 1998.

This work was supported by National Institutes of Health, National Institute of Neurological Disorders and Stroke grants NS01931 (J.W.M.), NS32636 (D.W.C.) and the American Paralysis Association (J.W.M., D.W.C.).

Correspondence should be sent to Dr. Dennis Choi, Department of Neurology, Box 8111, Washington University School of Medicine, 660 South Euclid Avenue, St. Louis, MO 63110.

Copyright (ㄷ) 1998 Society for Neuroscience $\quad 0270-6474 / 98 / 186290-10 \$ 05.00 / 0$ recovery of intracellular $\mathrm{Ca}^{2+}$ homeostasis, observed after $\mathrm{AM}$ PA-kainate receptor activation, but not after NMDA receptor activation or exposure to high $\mathrm{K}^{+}$. The ability of acidic $\mathrm{pH}$ to selectively augment AMPA-kainate receptor-mediated excitotoxicity may contribute to the prominent role that these receptors play in selective neuronal death after transient global ischemia.

Key words: AMPA; murine neuronal culture; $p H$; excitotoxicity; cyclothiazide; acidosis nal survival after either glutamate exposure (Koh and Choi, 1991) or oxygen-glucose deprivation (Goldberg and Choi, 1993). The reason for this appears to be masking of the relatively slowly triggered AMPA-kainate receptor-mediated injury by more fulminant, rapidly triggered NMDA receptor-mediated injury (Choi, 1992). Although exposure to AMPA or kainate will kill most cultured cortical neurons, much longer exposure (hours) is needed to induce widespread lethal injury by this route compared with the 3-5 min required to induce lethal injury by NMDA receptor overactivation. If NMDA receptors are blocked and the duration of oxygen-glucose deprivation extended to overcome associated neuroprotection, then AMPA-kainate antagonists produce substantial additional neuroprotective effects (Kaku et al., 1991).

How to reconcile these in vitro observations with data obtained in animal models of brain ischemia? A key may be the acidosis associated with lactic acid accumulation and subsequent reduction of $\mathrm{pH}$ that occurs in vivo, but not in vitro. Reduction of extracellular $\mathrm{pH}$ to levels found in ischemia in vivo (6.4-6.8) (Nemoto and Frinak, 1981; Siemkowicz and Hansen, 1981; Siesjo, 1988) markedly reduces NMDA receptor-mediated current (Tang et al., 1990), as well as NMDA receptor-mediated injury in cultured neurons (Giffard et al., 1990a; Tombaugh and Salpolsky, 1990; Kaku et al., 1993), and thus could help unmask more slowly triggered AMPA-kainate receptor-mediated injury. Extrapolating from studies of AMPA-kainate receptor-mediated currents, it has been assumed that AMPA-kainate receptor-mediated injury is attenuated by extracellular acid shift, but to a lesser degree than NMDA receptor-mediated injury (Giffard et al., 1990a; Christensen and Hida, 1990).

The purpose of the present experiments was to test this assumption directly.

An abstract has been published previously (McDonald et al., 1996a). 

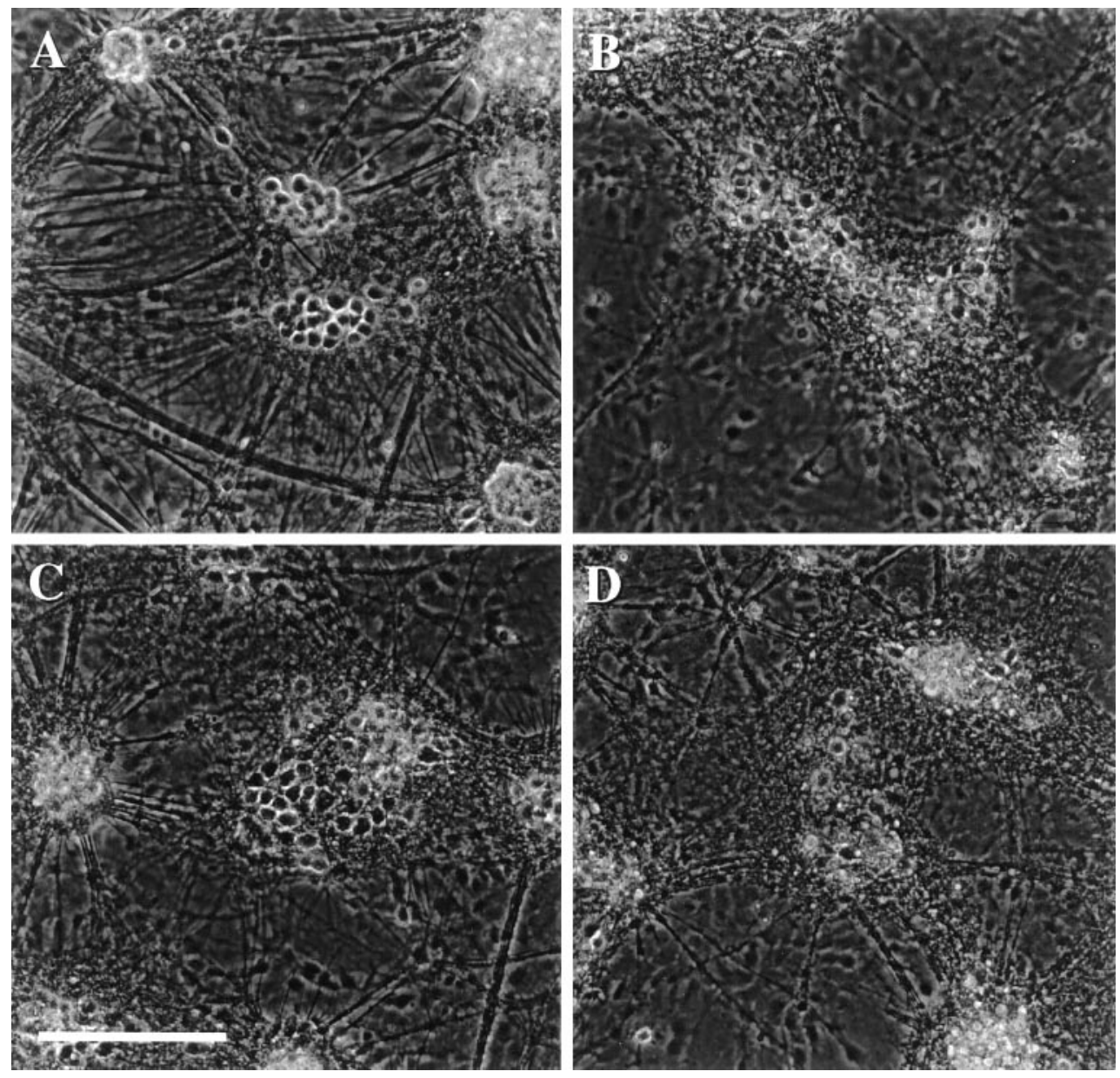

Figure 1. Acidic extracellular $\mathrm{pH}$ exacerbates slowly triggered AMPA toxicity. Phase-contrast micrographs of mixed cortical and glial cell cultures taken $18 \mathrm{hr}$ after $(A) 4 \mathrm{hr}$ exposure to $\mathrm{pH} 6.6$ alone (no change from sham wash controls); $(B)$ $24 \mathrm{hr}$ exposure to $300 \mu \mathrm{M} \mathrm{NMDA}$ at $\mathrm{pH}$ 7.4; (C) $4 \mathrm{hr}$ exposure to $300 \mu \mathrm{M}$ AMPA plus $10 \mu \mathrm{M}$ MK-801 at $\mathrm{pH} 7.4$ (this exposure, here and subsequently, was terminated by washing out AMPA and adding $10 \mu \mathrm{M}$ MK-801 plus $30 \mu \mathrm{M}$ NBQX); (D) 4 $\mathrm{hr}$ exposure to $300 \mu \mathrm{M}$ AMPA plus $10 \mu \mathrm{M}$ MK-801 at pH 6.6. Scale bar, $200 \mu \mathrm{m}$. All data are representative of at least three separate experiments.

\section{MATERIALS AND METHODS}

Cortical neuronal cultures. Mixed cortical cell cultures containing both neurons and astrocytes were prepared from fetal mice (15-16 d gestation) as previously described (Rose et al., 1992). Animals were handled in accordance with a protocol approved by our institutional animal care committee. Briefly, dissociated cortical cells were plated on a preexisting astrocyte monolayer (see below) at 2.5 hemispheres per 24 -well plate (a plating density of $\sim 2.5 \times 10^{5}$ cells per well). Plating media consisted of Eagle's minimal essential medium (MEM) (Earle's salts, supplied glutamine-free) supplemented with $5 \%$ fetal bovine serum, $5 \%$ horse serum, $2 \mathrm{~mm}$ glutamine and glucose to $20 \mathrm{~mm}$ final concentration. Non-neuronal cell division was halted at $3-5 \mathrm{~d}$ in vitro (DIV) by $3 \mathrm{~d}$ exposure to $10^{-5} \mathrm{M}$ cytosine arabinoside. Cultures were maintained in humidified $5 \% \mathrm{CO}_{2}$ incubators at $37^{\circ} \mathrm{C}$ and were used for experiments at 13-16 DIV. Medium was exchanged twice weekly with a growth medium identical to the plating medium, except lacking fetal bovine serum. Pure neuronal cultures were prepared in a similar manner with some modification (Rose et al., 1992).

Astrocyte cultures. Neocortical astrocyte cell cultures were prepared from postnatal mice aged 1-3 d (Rose et al., 1992) and plated at $0.25-0.5$ hemispheres per 24-well plate, in plating medium supplemented with 10 $\mathrm{ng} / \mathrm{ml}$ epidermal growth factor, $10 \%$ fetal bovine serum, and $10 \%$ horse serum. After 2 weeks in vitro, astrocyte cultures were fed weekly with growth medium and used over the next 2 weeks as a substrate for subsequent neuronal plating.

Neuronal toxicity experiments. Mixed neuron-astrocyte cultures (13-16 DIV) were exposed to AMPA in a physiological salt solution (at $37^{\circ} \mathrm{C}$ ) with the following composition (in $\mathrm{mM}$ ): $\mathrm{NaCl}, 120 ; \mathrm{KCl}, 5.4 ; \mathrm{MgSO}_{4}$, $0.8 ; \mathrm{NaH}_{2} \mathrm{PO}_{4}, 1.0 ; \mathrm{CaCl}_{2}, 1.8$; glucose, 5.5; PIPES, 20; and phenol red $10 \mathrm{mg} / \mathrm{l}$. The $\mathrm{NaHCO}_{3}$ concentration was varied as appropriate for the chosen $\mathrm{pH}$ in a $5 \% \mathrm{CO}_{2}$ atmosphere at $37^{\circ} \mathrm{C}$ (Dawson et al., 1986). Total $\left[\mathrm{Na}^{+}\right]$was maintained at $120 \mathrm{mM}$. Saturating concentrations of AMPA $(300 \mu \mathrm{M})$ and/or cyclothiazide $(100 \mu \mathrm{M})$ were used to avoid additive injury from secondary glutamate release. (+)-5-Methyl-10,11-dihydro-
5H-dibenzo[a,d]cyclohept-5,10-imine hydrogen maleate (MK-801) (10 $\mu \mathrm{M})$ was added with AMPA incubations to prevent NMDA receptor activation. Exposure was terminated by sequential washes $(>1000$-fold dilution) and transferred into Eagle's MEM supplemented with glucose $(25 \mathrm{~mm})$. All final incubations in experimental conditions contained saturating concentrations of NMDA and AMPA receptor antagonists [10 $\mu \mathrm{M}$ MK-801 and $30 \mu \mathrm{M}$ 6,7-dinitroquinoxaline-2,3-dione (NBQX)] to limit delayed secondary glutamate-induced injury. Although prolonged blockade of calcium influx may be associated with delayed apoptotic neuronal death, none was observed over $24 \mathrm{hr}$; addition of cycloheximide $(0.5 \mu \mathrm{g} / \mathrm{ml})$ or IGF-1 $(100 \mathrm{ng} / \mathrm{ml})$ did not provide additive protection when combined with MK-801 and NBQX. Cell death was assessed qualitatively by examination under phase contrast microscopy, and quantitatively by measuring lactate dehydrogenase (LDH) efflux into the extracellular medium (Koh and Choi, 1987). Background levels of LDH present in the medium of sham-washed sister cultures $(<10 \%$ total LDH) were subtracted from values measured in treatment conditions to yield the signal specifically associated with each condition. The LDH signal associated with near complete neuronal death was determined in sister cultures exposed to $300 \mu \mathrm{M}$ NMDA for $24 \mathrm{hr}$, an exposure that reliably destroyed the neuronal population without concurrent glial death. All data are presented relative to LDH measurements associated with complete neuronal death in sister cultures (100). In additional experiments, cell viability was assessed by exclusion of $0.4 \%$ trypan blue dye.

Oxygen-glucose deprivation experiments. Combined oxygen-glucose deprivation was initiated by exposing neuronal cultures to a deoxygenated, glucose-free solution at $\mathrm{pH} 6.4$ or 7.4 [glucose-free Earle's balanced salt solution (BSS)], in an air-tight chamber flooded with $95 \% \mathrm{~N}_{2}$ and $5 \%$ $\mathrm{CO}_{2}$ (Goldberg and Choi, 1993). BSS contained (in mM): $\mathrm{Na}^{+}, 143.6$; $\mathrm{K}^{+}, 5.4 ; \mathrm{Ca}^{2+}, 1.8 ; \mathrm{Mg}^{2+}, 0.8 ; \mathrm{Cl}^{-}, 125.3 ; \mathrm{HCO}^{-}, 26.2 ; \mathrm{H}_{2} \mathrm{SO}_{4}{ }^{2-}, 1.0$; $\mathrm{SO}_{4}{ }^{2-}, 0.8$; and phenol red, $10 \mathrm{mg} / 1$. Exposure times of $50 \mathrm{~min}, \mathrm{pH} 7.4$, and $75 \mathrm{~min}, \mathrm{pH}$ 6.4, were chosen to match total neuronal injury between $\mathrm{pH}$ exposures (70-80\% death), because acid $\mathrm{pH}$ reduces oxygen-glucose deprivation injury (Giffard et al., 1990a). Deprivation was terminated by 


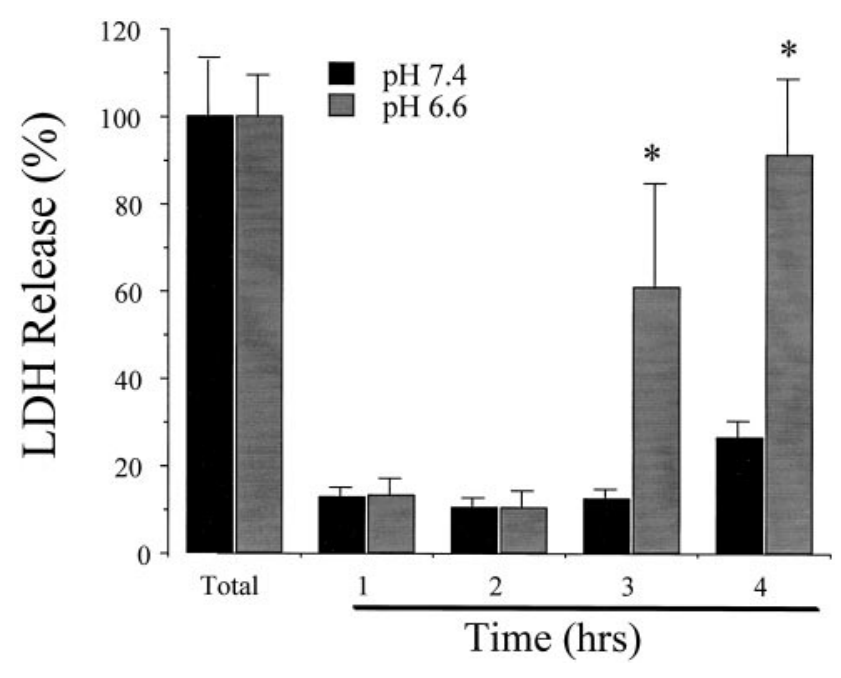

Figure 2. Time course of AMPA-induced neuronal death at $\mathrm{pH} 7.4$ and 6.6. Sister cultures were incubated in HBSS containing $300 \mu \mathrm{M}$ AMPA and $10 \mu \mathrm{M}$ MK-801 for the indicated periods. LDH release to the bathing medium was measured $24 \mathrm{hr}$ later (mean $\pm \mathrm{SEM}, n=4$ ) and scaled to the level (100) measured in sister cultures exposed to $300 \mu \mathrm{M}$ NMDA for 24 hr (a condition that produced near complete neuronal death without astrocyte death). Background LDH release in sister cultures exposed to sham wash alone was subtracted from each condition to yield the signal specific to experimental injury. *Difference at $p<0.05$, from corresponding time value at $\mathrm{pH} 7.4$, by Student's two-tailed independent $t$ test.

replacing the exposure medium with oxygenated BSS, $\mathrm{pH} 7.4$, containing $5.5 \mathrm{~mm}$ glucose, and cultures were returned to normoxic incubator. Cell injury was assessed $24 \mathrm{hr}$ later by LDH efflux and phase-contrast microscopy as described above.

${ }^{45} \mathrm{Ca}^{2+}$ accumulation studies. Cultures were washed, then incubated in the physiological buffer described above containing (in $\mu \mathrm{M}$ ): 300 AMPA, 100 cyclothiazide, $10 \mathrm{MK}-801$, and ${ }^{45} \mathrm{Ca}^{2+}$ (New England Nuclear; final activity, $0.5-1 \mathrm{mCi} / \mathrm{ml}$ ) at $\mathrm{pH} 7.4$ or 6.6 , for 5,15 , or 30 min (Hartley et al., 1993). Exposure was terminated by thorough washout of extracellular ${ }^{45} \mathrm{Ca}^{2+}$. Cells were lysed with $0.2 \%$ SDS solution at $37^{\circ} \mathrm{C}$ to measure intracellular ${ }^{45} \mathrm{Ca}^{2+}$ accumulation. ${ }^{45} \mathrm{Ca}^{2+}$ accumulation in shamwashed sister cultures was subtracted from all values to yield the ${ }^{45} \mathrm{Ca}^{2+}$ accumulation specific to each condition tested. The mean value of ${ }^{45} \mathrm{Ca}^{2+}$ accumulation for each condition was scaled to that induced by $500 \mu \mathrm{M}$ NMDA (100).

Intracellular free $\mathrm{Ca}^{2+}$ determination. Intracellular free $\mathrm{Ca}^{2+}$ $\left(\left[\mathrm{Ca}^{2+}\right]_{\mathrm{i}}\right)$ was measured using fura-2 fluorescence video microscopy (Grynkiewicz et al., 1985). Neuronal cultures for $\left[\mathrm{Ca}^{2+}\right]_{\mathrm{i}}$ imaging experiments were prepared as previously described, and experiments were performed between 12-17 DIV (Csernansky et al., 1994). Cells were loaded with $5 \mu \mathrm{M}$ fura-2 AM plus $0.1 \%$ Pluronic F-127 for $30 \mathrm{~min}$ at room temperature $\left(24^{\circ} \mathrm{C}\right)$, washed, and incubated for an additional 30 min in HBSS. All experiments were performed using the same bicarbonate-buffered salt solution as used for the toxicity studies. Experiments were performed at room temperature on the stage of a Nikon Diaphot inverted microscope equipped with a $75 \mathrm{~W}$ Xenon lamp and a Nikon $40 \times, 1.3$ NA epifluorescence oil immersion objective under continuous perfusion (perfusion rate, $2 \mathrm{ml} / \mathrm{min}$ ). Although temperature may alter many cellular functions, we have observed previously that temperature does not substantially alter NMDA or kainate-stimulated peak $\left[\mathrm{Ca}^{2+}\right]_{\mathrm{i}}$ responses or recovery (Bruno et al., 1994). In addition to room temperature experiments, a set of additional fura-2 measurements was performed at $37^{\circ} \mathrm{C}$ to coincide with toxicity studies. Fura-2 (Ex $\lambda=340$, $380 \mathrm{~nm}, \operatorname{Em} \lambda=510 \mathrm{~nm}$ ) ratio images were acquired with an intensified CCD (Quantex) camera and digitized $(256 \times 512$ pixels $)$ using an Image-1 (Universal Imaging Corporation, West Chester, PA) system. Calibrated $\left[\mathrm{Ca}^{2+}\right]_{\mathrm{i}}$ values were obtained using the ratio method of Grynkiewicz et al. (1985) by determining $F_{\min }$ and $F_{\max }$ in situ using EGTA $(10 \mathrm{mM})$ with $0 \mathrm{Ca}^{2+}$ buffer and ionomycin $(10 \mu \mathrm{M})$ for $F_{\min }$ and $10 \mathrm{mM} \mathrm{Ca}^{2+}$ with ionomycin $(10 \mu \mathrm{M})$ for $\mathrm{F}_{\max }$. A $K_{\mathrm{d}}$ value of $225 \mathrm{nM}$ $\mathrm{Ca}^{2+}$ was used for fura-2.

Materials. Cyclothiazide was obtained from Eli Lilly and Co. (India-
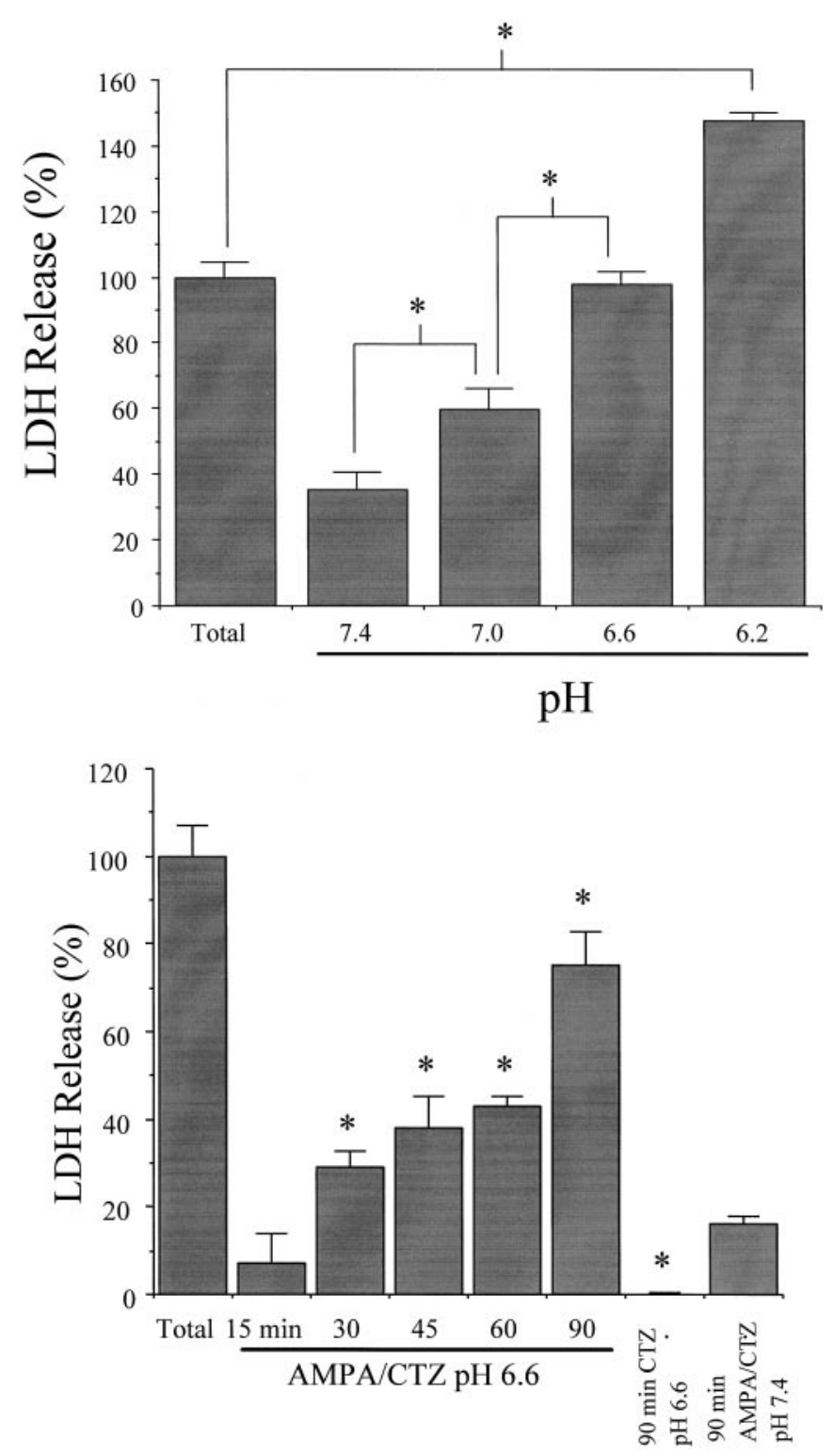

Figure 3. Acidic extracellular $\mathrm{pH}$ exacerbates rapidly triggered AMPA toxicity. $A$, Mixed cultures were exposed for $1.5 \mathrm{hr}$ to $300 \mu \mathrm{M}$ AMPA plus $100 \mu \mathrm{M}$ cyclothiazide and $10 \mu \mathrm{M} \mathrm{MK}-801$ at the indicated extracellular $\mathrm{pH}$ (mean $\pm \mathrm{SEM}, n=4)$. At $\mathrm{pH} 6.2$ (but not at higher $\mathrm{pH}$ ), some astrocyte death also occurred, accounting for the total LDH release exceeding 100. *Difference at $p<0.05$, as indicated, by one-way ANOVA with Student Newman-Keuls test. $B$, Time course of rapidly triggered AMPA toxicity at $\mathrm{pH}$ 6.6. Neuronal cultures were exposed to $300 \mu \mathrm{M}$ AMPA plus $100 \mu \mathrm{M}$ cyclothiazide and $10 \mu \mathrm{M}$ MK-801 at $\mathrm{pH} 6.6$ for the indicated duration. *Difference at $p<0.05$, one-way ANOVA with Student Newman-Keuls test, indicated time AMPA-cyclothiazide (CTZ) at $\mathrm{pH} 6.6$ versus $90 \mathrm{~min}$ exposure AMPA-CTZ at $\mathrm{pH} 7.4$ ( far right bar). Exposure to cyclothiazide alone at $\mathrm{pH} 6.6$ for 90 min produced no neuronal death (*difference at $p<0.05,90 \mathrm{~min} \mathrm{CTZ}$ at $\mathrm{pH} 6.6$ vs $90 \mathrm{~min}$ AMPA-CTZ at $\mathrm{pH} 7.4$, Student's independent $t$ test). LDH release to the bathing medium was measured $24 \mathrm{hr}$ later (mean $\pm \mathrm{SEM}, n=4)$ and scaled to the level (100) measured in sister cultures exposed to $300 \mu \mathrm{M}$ NMDA for $24 \mathrm{hr}$.

napolis, IN). Comparison toxicity studies were performed with cyclothiazide from another source (Research Biochemicals International, Natick, MA). Cyclothiazide was dissolved in DMSO as a $30 \mathrm{~mm}$ stock solution and stored at $4^{\circ} \mathrm{C}$. Similar experimental observations were obtained with drug from both sources. All other chemicals were obtained from commercial sources. 


\begin{tabular}{lc}
\hline $\begin{array}{l}\text { Table 1. Kainate-induced cortical neuronal death is enhanced at acidic } \\
\text { pH }\end{array}$ & $\%$ Neuronal death \pm SEM \\
Treatment & \\
\hline pH 7.4 & $19 \pm 5$ \\
Kainate & $1 \pm 0.3^{*}$ \\
Kainate + NBQX & \\
pH 6.6 & $50 \pm 4^{* *}$ \\
Kainate & $2 \pm 0.4^{*}$ \\
Kainate + NBQX &
\end{tabular}

Reducing extracellular $\mathrm{pH}$ from 7.4 to 6.6 enhanced cortical neuron death induced by $20 \mathrm{~min}$ exposure to $200 \mu \mathrm{M}$ kainate. MK-801 $(10 \mu \mathrm{M})$ was included with each exposure. Coapplication of NBQX $(30 \mu \mathrm{M})$ prevented death induced by kainate under both conditions. LDH release to the bathing medium was measured $24 \mathrm{hr}$ later (mean \pm SEM, $n=8$ ), scaled to the level (100) measured in sister cultures exposed to $300 \mu \mathrm{M}$ NMDA for $24 \mathrm{hr}$ (a condition that produced near complete neuronal death without astrocyte death). Background LDH release in sister cultures exposed to sham wash alone was subtracted from each condition to yield the signal specific to experimental injury.

*Difference at $p<0.05$ from kainate exposure alone at same $\mathrm{pH}$, by Student's independent $t$ test.

**Difference at $p<0.05$ from kainate exposure at $\mathrm{pH} 7.4$.

\section{RESULTS}

\section{Effects of extracellular pH on AMPA- and kainate- induced neuronal injury}

We previously reported that multihour exposure to AMPA was required to induce widespread neuronal death in murine cortical cell cultures at $\mathrm{pH} 7.4$ (Koh et al., 1990). At $\mathrm{pH} 7.4,3-4 \mathrm{hr}$ exposure of mixed (neuronal plus astrocyte) cultures (13-16 DIV) to $300 \mu \mathrm{M}$ AMPA in the presence of $10 \mu \mathrm{M}$ MK-801 (added to block secondary NMDA receptor-mediated injury) produced extensive acute neuronal cell swelling but little late neuronal death and LDH release by the next day (Figs. 1, 2). At pH 6.6, the same exposure induced both acute neuronal cell swelling and substantial late neuronal death by the next day (still without astrocyte death) (Figs. 1, 2). Neuronal death was prevented by coapplication of the selective AMPA-kainate receptor antagonist NBQX $(30 \mu \mathrm{M})$. Exposure to $\mathrm{pH} 6.6$ alone for 3-4 hr produced little cell death. Continued exposure of cultures to acid $\mathrm{pH}$, beyond the period of AMPA or kainate exposure, did not prevent neuronal death (data not shown). To examine if the potentiation of AMPA-kainate receptor toxicity at acidic $\mathrm{pH}$ was related to additive effects of two sublethal injuries, similar $\mathrm{pH}$ exposures were performed with another $\mathrm{Ca}^{2+}$-overload injury paradigm. Intermediate levels of neuronal death induced by a $3 \mathrm{hr}$ exposure to the $\mathrm{Ca}^{2+}$ ionophore $\mathrm{A} 23187(100-500 \mu \mathrm{M})$ at $\mathrm{pH} 7.4$ was not potentiated by coexposure to acidic $\mathrm{pH}$ (6.6) when examined 24 hr later (data not shown).

To determine whether the same injury potentiation could be detected with shorter exposure duration, we exploited the ability of cyclothiazide to inhibit AMPA receptor desensitization and potentiate AMPA receptor-mediated neuronal death (Yamada and Rothman, 1992; May and Robinson, 1993; Patneau et al., 1993; Zorumski et al., 1993; Moudy et al., 1994). Exposure of mixed neuronal-astrocyte cultures for $1.5 \mathrm{hr}$ to (in $\mu \mathrm{M}$ ): 300 AMPA, 100 cyclothiazide, and 10 MK-801 resulted in increasing neuronal death without astrocyte death (trypan blue exclusion; data not shown) as bath $\mathrm{pH}$ was shifted from 7.4 to 6.6 (Fig. $3 A$ ). When bath was further shifted to $\mathrm{pH} 6.2$, substantial astrocyte death also occurred (Fig. 3A; David et al., 1996). A $1.5 \mathrm{hr}$ exposure to $\mathrm{pH} 6.6$ alone produced little neuronal injury $(4 \pm 6 \%$ LDH release, $n=8$ ).
Table 2. Acidic extracellular pH increases the contribution of AMPAkainate receptors to oxygen-glucose deprivation injury

Treatment

$\%$ Neuronal death \pm SEM

pH 7.4

OGD (50 min) $\quad 65 \pm 3$

OGD $(50 \mathrm{~min})+\mathrm{NBQX} \quad 66 \pm 5$

pH 6.4

OGD (75 min) $\quad 84 \pm 6$

OGD (75 min) + NBQX $63 \pm 6^{*}$

Addition of $30 \mu \mathrm{M}$ NBQX did not reduce neuronal death in cultures exposed to 50 min of oxygen-glucose deprivation at $\mathrm{pH} 7.4$ but did partially reduce neuronal death in cultures exposed to oxygen-glucose deprivation at $\mathrm{pH}$ 6.4. Because reducing $\mathrm{pH}$ reduced NMDA receptor-mediated toxicity and overall neuronal death, in the latter condition the duration of oxygen-glucose deprivation was increased to $75 \mathrm{~min}$ to recover widespread neuronal death comparable to corresponding injury with $50 \mathrm{~min}$ oxygen-glucose deprivation at $\mathrm{pH}$ 7.4. Data are mean $\pm \operatorname{SEM}(n=8)$. Neuronal cell death was quantitated by measuring LDH released into the bathing medium $24 \mathrm{hr}$ later.

*Difference at $p<0.05$ from 75 min oxygen-glucose deprivation at $\mathrm{pH}$ 6.4, by Student's two-tailed independent $t$ test.

Lowering extracellular $\mathrm{pH}$ to 6.6 permitted relatively brief (30 min or more) duration exposure to $300 \mu \mathrm{M}$ AMPA plus $100 \mu \mathrm{M}$ cyclothiazide to become neurotoxic (Fig. $3 B$ ). Nearly complete neuronal death was induced by a $1.5 \mathrm{hr}$ exposure to AMPA and cyclothiazide at pH 6.6 (Fig. $3 B$ ). Application of cyclothiazide alone at $\mathrm{pH} 6.6$ for $1.5 \mathrm{hr}$ did not produce neuronal death.

Reduction of extracellular $\mathrm{pH}$ to 6.6 also potentiated (twofold) neuronal death resulting from exposure to $200 \mu \mathrm{M}$ kainate (Table 1). Neuronal death was prevented by coexposure to $30 \mu \mathrm{M}$ NBQX.

\section{Effect of reduced extracellular pH on oxygen-glucose deprivation-induced neuronal injury}

Oxygen-glucose deprivation-induced death in cortical neuronal cultures at $\mathrm{pH} 7.4$ is predominantly attributable to NMDA receptor-mediated toxicity (Choi, 1992). We examined whether the contribution of AMPA receptors to this death would increase

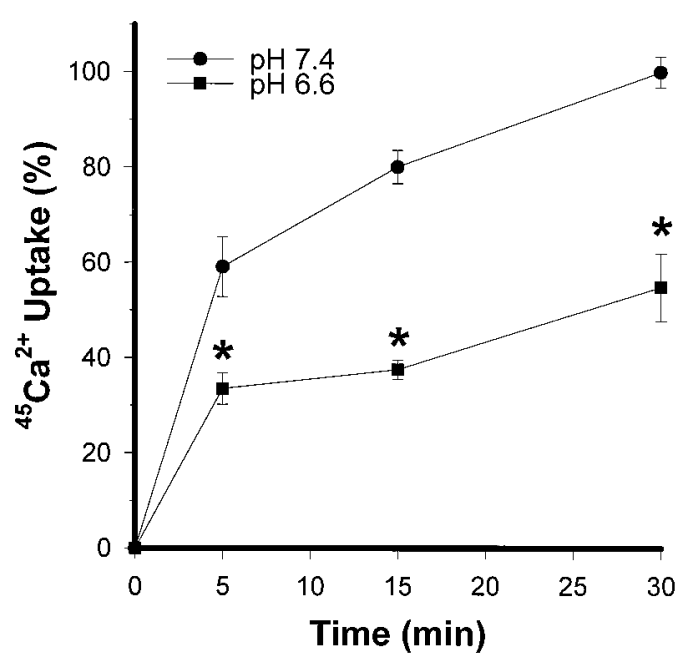

Figure 4. Acidic $\mathrm{pH}$ exacerbation of AMPA toxicity is associated with reduced ${ }^{45} \mathrm{Ca}$ uptake. Mixed cultures were incubated with $300 \mu \mathrm{M}$ AMPA plus $100 \mu \mathrm{M}$ cyclothiazide and $10 \mu \mathrm{M} \mathrm{MK}-801$ at $\mathrm{pH} 7.4$ or 6.6 , for the indicated times. Cellular ${ }^{45} \mathrm{Ca}$ accumulation (mean $\pm \mathrm{SEM}, n=7$ ) was scaled to the levels obtained in sister cultures exposed to $500 \mu \mathrm{M}$ NMDA for $15 \mathrm{~min}$ (100). Basal ${ }^{45} \mathrm{Ca}$ uptake in sham-washed sister cultures was subtracted from all measurements. *Difference at $p<0.05$, from corresponding time point at $\mathrm{pH} 7.4$, by one-way ANOVA and Student Newman-Keuls test. 

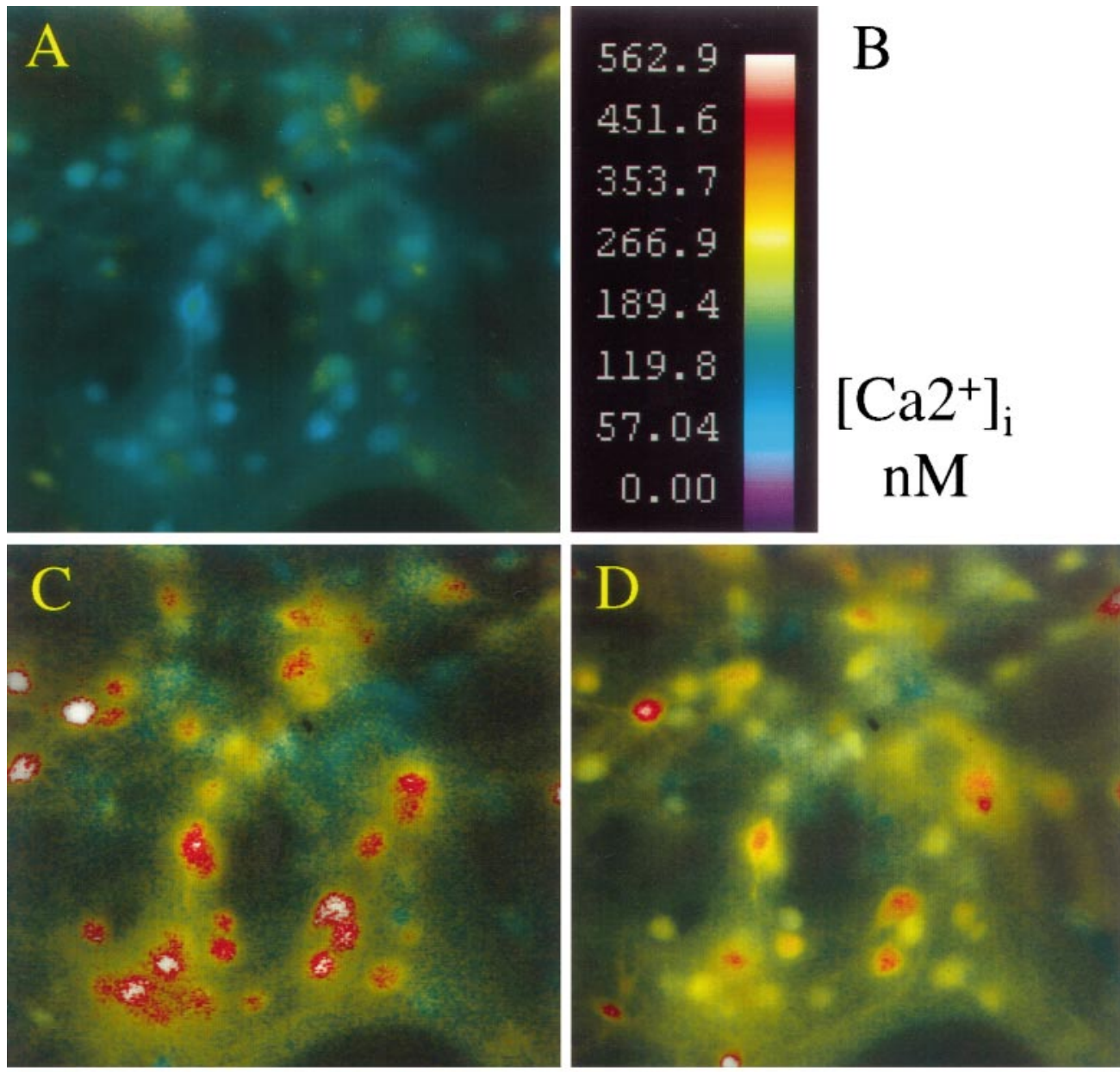

Figure 5. Reducing extracellular $\mathrm{pH}$ attenuates the peak $\left[\mathrm{Ca}^{2+}\right]_{\mathrm{i}}$ response to AMPA but delays subsequent normalization. Pseudocolor images, shown as intensity modulated display, of intracellular free calcium in the same field of neurons exposed to 10 $\mu \mathrm{M}$ AMPA at pH 7.4 or $6.6\left(24^{\circ} \mathrm{C}\right) . A$, Basal $\left[\mathrm{Ca}^{2+}\right]_{\mathrm{i}}$ measurements in cortical neurons at rest in $\mathrm{pH} 7.4$ buffer. $B$, Calibration scale. $C-D$, Peak responses during a $5 \mathrm{sec}$ application of $10 \mu \mathrm{M}$ AMPA plus $10 \mu \mathrm{M}$ cyclothiazide and $10 \mu \mathrm{M}$ MK-801 at pH $7.4(C)$ or at $\mathrm{pH} 6.6(D) . E-F$, Corresponding fields as $C-D$, but measured $15 \mathrm{~min}$ after drug washout. Peak $\left[\mathrm{Ca}^{2+}\right]_{i}$ measurements are reduced by acidic $\mathrm{pH}$, but response recovery is impaired.
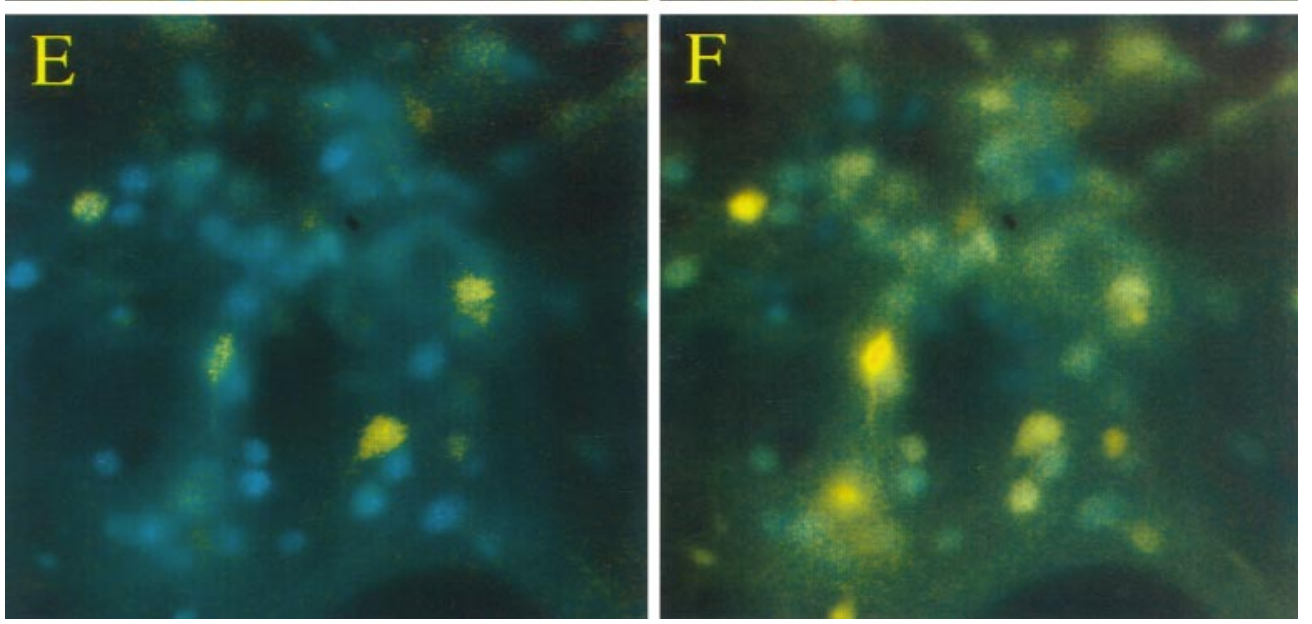

Figure 6. Changes in $\left[\mathrm{Ca}^{2+}\right]_{\mathrm{i}}$ after exposure to AMPA, kainate, NMDA, or high $\mathrm{KCl}$ at normal and acidic pH. Refer to Table 3 for corresponding calcium integral measurements. All measurements were performed at $24^{\circ} \mathrm{C}$. $A$, AMPA response; sequential averaged changes in $\left[\mathrm{Ca}^{2+}\right]_{\mathrm{i}}$ in 35 neurons during and after a $5 \mathrm{sec}$ exposure to $10 \mu \mathrm{M}$ AMPA plus $100 \mu \mathrm{M}$ cyclothiazide and $10 \mu \mathrm{M} \mathrm{MK}-801$ at $\mathrm{pH} 7.4$ or 6.6. Exposure to acidic pH attenuates peak AMPA responses but impairs recovery. $B$, Kainate-induced $\left[\mathrm{Ca}^{2+}\right]_{\mathrm{i}}$ responses at $\mathrm{pH} 7.4$ and 6.6 were similar to that observed for AMPA. Cultures were exposed to $100 \mu \mathrm{M}$ kainate, as outlined in $A$. Peak responses are attenuated at $\mathrm{pH}$ 6.6, but again, normalization was markedly impaired. $C$, Reducing extracellular $\mathrm{pH}$ attenuates the peak $\left[\mathrm{Ca}^{2+}\right]_{\mathrm{i}}$ response to NMDA with minimal change in subsequent normalization. The trace represents average $(n=$ 27 neurons) changes in $\left[\mathrm{Ca}^{2+}\right]_{\mathrm{i}}$ during and after $5 \mathrm{sec}$ exposures to $50 \mu \mathrm{M} \mathrm{NMDA}$ at $\mathrm{pH} 7.4$ or 6.6. In the low pH exposure experiments, neurons were washed for $5 \mathrm{~min}$ at $\mathrm{pH} 6.6$ before the application of NMDA, exposed to NMDA at $\mathrm{pH} 7.4$ for $5 \mathrm{sec}$, and immediately returned at $\mathrm{pH} 6.6$ for 15 min. Under these conditions the intracellular $\mathrm{pH}$ remains below 6.6, and the brief extracellular exposure to NMDA (Figure legend continues.) 

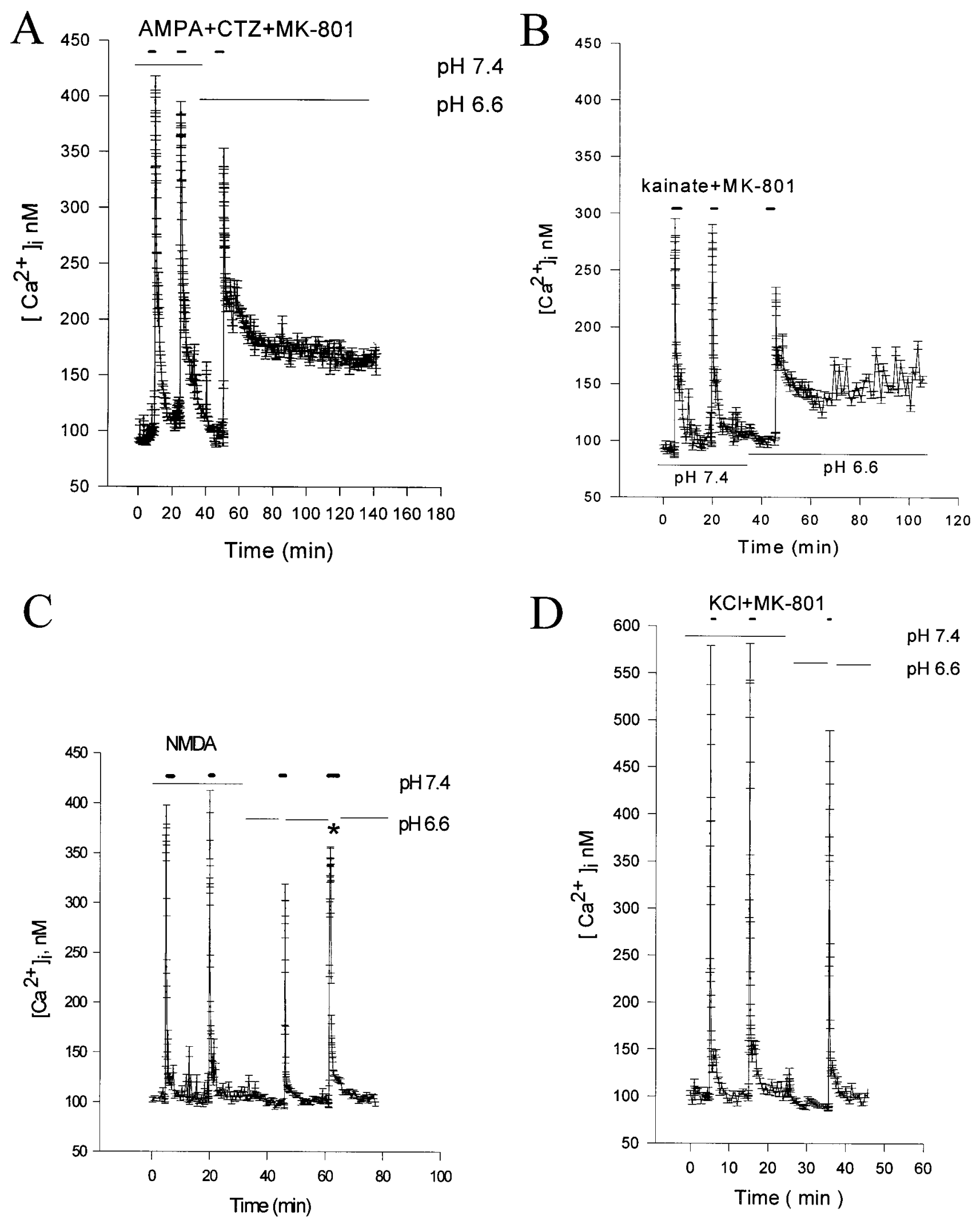

(Figure legend continued.) at $\mathrm{pH} 7.4$ allows activation of NMDA receptors (i.e., the pH-sensitive site on NMDA receptors is extracellular). $D$, Reducing extracellular $\mathrm{pH}$ attenuates the peak $\left[\mathrm{Ca}^{2+}\right]_{\mathrm{i}}$ response to high $\mathrm{KCl}$ with minimal change in subsequent normalization. The trace represents average $(n=$ 30 neurons) changes in $\left[\mathrm{Ca}^{2+}\right]_{\mathrm{i}}$ during and after $5 \mathrm{sec}$ exposures to $60 \mathrm{mM} \mathrm{KCl}$ plus $10 \mu \mathrm{M} \mathrm{MK}-801$ at $\mathrm{pH} 7.4$ or 6.6 . In the low pH exposure experiments, neurons were washed for $5 \mathrm{~min}$ at $\mathrm{pH} 6.6$ before the application of $60 \mathrm{mM} \mathrm{KCl}$, exposed to high $\mathrm{KCl}$ at $\mathrm{pH} 7.4$, and immediately returned to $\mathrm{pH} 6.6$ for $15 \mathrm{~min}$. Under these conditions, the intracellular $\mathrm{pH}$ remains below 6.6, and the brief extracellular exposure to $60 \mathrm{~mm} \mathrm{KCl}$ at $\mathrm{pH} 7.4$ allows activation of voltage-sensitive calcium channels. All the experiments are representative of at least three different experiments in three different cultures. 


\begin{tabular}{|c|c|c|c|c|c|}
\hline \multirow[b]{2}{*}{ Trigger } & \multirow[b]{2}{*}{ No. of cells tested } & \multicolumn{2}{|c|}{$\begin{array}{l}\text { Area under curve (mean } \pm \text { SEM, } \\
\text { arbitrary units) }\end{array}$} & \multirow{2}{*}{$\begin{array}{l}\text { Value ratio } \\
6.6 / 7.4\end{array}$} & \multirow{2}{*}{$\begin{array}{l}\text { Difference at } \\
p<0.05\end{array}$} \\
\hline & & $\mathrm{pH} 7.4$ & $\mathrm{pH} 6.6$ & & \\
\hline AMPA & 167 & $11.0 \pm 0.2$ & $39.1 \pm 0.4$ & 3.5 & Yes \\
\hline Kainate & 122 & $8.0 \pm 0.1$ & $15.1 \pm 0.2$ & 1.9 & Yes \\
\hline NMDA & 212 & $8.2 \pm 0.1$ & $6.6 \pm 0.1$ & 0.8 & Yes \\
\hline $\mathrm{KCl}$ & 187 & $7.0 \pm 0.1$ & $6.3 \pm 0.1$ & 0.9 & Yes \\
\hline
\end{tabular}

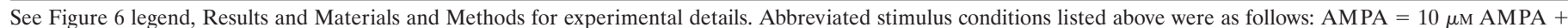

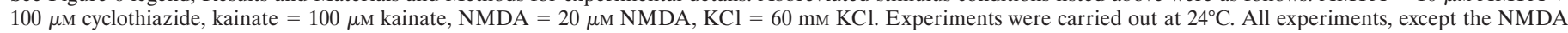

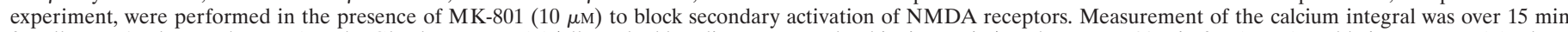

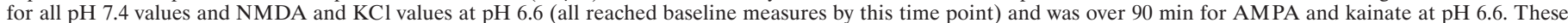

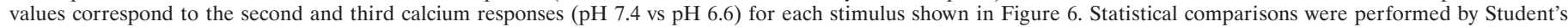
two-tailed independent $t$ test.

as a result of reducing extracellular $\mathrm{pH}$. Although neuronal death resulting from 50 min exposure to oxygen-glucose deprivation at pH 7.4 was not altered by AMPA receptor blockade with $30 \mu \mathrm{M}$ NBQX, death induced by 75 min exposure at $\mathrm{pH} 6.4$ was sensitive to NBQX (Table 2). We have previously shown that acidic extracellular $\mathrm{pH}$ (6.4) attenuates oxygen-glucose deprivation-induced death of cortical neurons. Because reducing $\mathrm{pH}$ reduced overall neuronal death, in the latter condition the duration of oxygenglucose deprivation was increased to $75 \mathrm{~min}$ to recover widespread neuronal death comparable to corresponding injury with 50 min oxygen-glucose deprivation at $\mathrm{pH} 7.4$

\section{${ }^{45} \mathrm{Ca}^{2+}$ accumulation}

Because toxic $\mathrm{Ca}^{2+}$ influx appears to be a critical event in excitotoxic necrosis (Choi, 1987, 1992), we tested whether the potentiating effect of reduced extracellular $\mathrm{pH}$ on the toxicity of AMPA plus cyclothiazide was accompanied by increases in $\mathrm{Ca}^{2+}$ influx, as measured by a ${ }^{45} \mathrm{Ca}^{2+}$ uptake assay (Hartley et al., 1993). Paradoxically, the enhanced neuronal vulnerability to AMPA toxicity observed in mixed cultures at reduced extracellular $\mathrm{pH}$ was not associated with increased ${ }^{45} \mathrm{Ca}^{2+}$ accumulation but rather was associated with reduced ${ }^{45} \mathrm{Ca}^{2+}$ accumulation (Fig. 4), consistent with previous electrophysiological data indicating reduced kainate-activated whole-cell current in cultured cortical neurons and cone horizontal cells at acidic $\mathrm{pH}$ (Christensen and Hida, 1990; Giffard et al., 1990a).

Because reduced astrocyte ${ }^{45} \mathrm{Ca}^{2+}$ accumulation in response to acid $\mathrm{pH}$ shift could mask an increase in neuronal ${ }^{45} \mathrm{Ca}^{2+}$ accumulation, we also examined ${ }^{45} \mathrm{Ca}^{2+}$ accumulation in pure neuronal cultures. A similar decrease in ${ }^{45} \mathrm{Ca}^{2+}$ accumulation occurred at acid pH. Sister cultures of near-pure neurons (13 DIV) were exposed to (in $\mu \mathrm{M}$ ): 300 AMPA, 100 cyclothiazide, $10 \mu \mathrm{M}$ MK801, and ${ }^{45} \mathrm{Ca}^{2+}$, pH 7.4 or $6.6 .{ }^{45} \mathrm{Ca}^{2+}$ accumulation was examined 5 min later and values were normalized to ${ }^{45} \mathrm{Ca}^{2+}$ accumulation induced by $500 \mu \mathrm{M}$ NMDA at $\mathrm{pH} 7.4 .{ }^{45} \mathrm{Ca}^{2+}$ accumulation was reduced by $44 \%$ at $\mathrm{pH} 6.6$ compared with $\mathrm{pH} 7.4$ (difference at $p<0.05$ by Student's two tailed independent $t$ test; $\mathrm{pH} 7.4$, $61 \pm 2 \mathrm{vs} \mathrm{pH} \mathrm{6.6,} 34 \pm 3$; mean $\pm \mathrm{SEM}, n=24$ per condition).

\section{Intracellular free $\mathrm{Ca}^{2+}$ determination}

To assess whether impaired $\left[\mathrm{Ca}^{2+}\right]_{\mathrm{i}}$ buffering at reduced $\mathrm{pH}$ may render neurons more vulnerable to AMPA toxicity, we performed intracellular free $\left[\mathrm{Ca}^{2+}\right]_{\mathrm{i}}$ imaging using fura-2. Neuronal cultures exposed for $5 \mathrm{sec}$ to $10 \mu \mathrm{M}$ AMPA (plus $100 \mu \mathrm{M}$ cyclothiazide and $10 \mu \mathrm{M} \mathrm{MK}-801)$ at $\mathrm{pH} 6.6\left(24^{\circ} \mathrm{C}\right)$, exhibited a marked delayed recovery of $\left[\mathrm{Ca}^{2+}\right]_{\mathrm{i}}$ to baseline compared with sister cultures exposed to AMPA at $\mathrm{pH} 7.4$, despite a predictable reduction of the peak $\left[\mathrm{Ca}^{2+}\right]_{\mathrm{i}}$ response (Figs. 5, 6A; Table 3). Similar observations were also made when experiments were performed at $37^{\circ} \mathrm{C}$ (data not shown). This delayed recovery was apparent across the whole neuronal population, and it was not dependent on stimulus sequence. A delayed recovery of $\left[\mathrm{Ca}^{2+}\right]_{i}$ was also seen in cultures exposed to kainate plus MK-801 (Fig. $6 B)$. The impaired recovery was long lasting, and extended at least $1.5 \mathrm{hr}$ after removal of kainate or AMPA. Delayed recovery persisted despite return of extracellular $\mathrm{pH}$ to 7.4 (data not shown).

To determine whether this effect was selective for AMPAkainate responses, we examined the effect of $\mathrm{pH}$ on NMDA- and $\mathrm{KCl}$-induced $\left[\mathrm{Ca}^{2+}\right]_{\mathrm{i}}$. Cells were preincubated at $\mathrm{pH} 6.6$ for 10 min, and then $50 \mu \mathrm{M}$ NMDA was applied for $5 \mathrm{sec}$ (at $\mathrm{pH} 7.4$, because application at $\mathrm{pH} 6.6$ produces little response). In control experiments, we demonstrated that this paradigm produces well maintained intracellular acidification despite the brief application of $\mathrm{pH} 7.4$ buffer (data not shown). Application of NMDA induced a rapid and large increase in neuronal $\left[\mathrm{Ca}^{2+}\right]_{\mathrm{i}}$, but recovery was not delayed at pH 6.6 (Fig. $6 C$, Table 3). A $>10$-fold increase in exposure time to NMDA (60 sec), resulting in peak responses comparable with AMPA-kainate exposure, did not delay $\left[\mathrm{Ca}^{2+}\right]_{\mathrm{i}}$ recovery. Despite even higher peak $\left[\mathrm{Ca}^{2+}\right]_{\mathrm{i}}$ responses produced by $60 \mathrm{mM} \mathrm{KCl}$ at $\mathrm{pH} 6.6,\left[\mathrm{Ca}^{2+}\right]_{\mathrm{i}}$ recovery was not impaired (Fig. $6 D$, Table 3), suggesting a specific effect of reduced extracellular $\mathrm{pH}$ on AMPA receptor-mediated $\left[\mathrm{Ca}^{2+}\right]_{\mathrm{i}}$ responses.

\section{DISCUSSION}

The major finding of the present study is the novel and unexpected observation that reduction of extracellular $\mathrm{pH}$ to levels of acidity associated with ischemia in vivo (Nemoto and Frinak, 1981; Siemkowicz and Hansen, 1981; Tombaugh and Sapolsky, 1993; Siesjo, 1988) paradoxically potentiated AMPA-kainate receptor-mediated cortical neuronal death. This potentiation extended to the AMPA-kainate receptor-mediated component of oxygen-glucose deprivation-induced neuronal death. Acid $\mathrm{pH}$ potentiation of AMPA-kainate receptor-mediated toxicity occurred despite a reduction in both net influx of ${ }^{45} \mathrm{Ca}^{2+}$ and peak increase in $\left[\mathrm{Ca}^{2+}\right]_{i}$, most likely because subsequent normalization of $\left[\mathrm{Ca}^{2+}\right]_{\mathrm{i}}$ was selectively impaired. Elevated $\left[\mathrm{Ca}^{2+}\right]_{\mathrm{i}}$ persisted for $>90$ min after termination of AMPA or kainate exposure, even after return to normal extracellular pH. Similarly delayed normalization of $\left[\mathrm{Ca}^{2+}\right]_{i}$ was not seen after comparable peak elevations induced by exposure to NMDA or high $\mathrm{K}^{+}$. The brief, multisecond exposures to AMPA, NMDA, and high $\mathrm{K}^{+}$ 
used in the fura- 2 studies were intended to probe calcium handling and were not sufficient to produce detectable injury or neuronal death. It is therefore unlikely that the delayed normalization of $\left[\mathrm{Ca}^{2+}\right]_{\mathrm{i}}$ after AMPA receptor activation at acidic $\mathrm{pH}$ can be explained by lethal injury. The observation that acidic $\mathrm{pH}$ did not enhance intermediate levels of neuronal death induced by exposure to the calcium ionophore A23187, suggests that the potentiation of AMPA-kainate receptor toxicity at acidic $\mathrm{pH}$ is not a simple reflection of additive sublethal injury.

The ability of acid pH to enhance AMPA-kainate receptormediated injury is especially striking when placed in the context of reduced net $\mathrm{Ca}^{2+}$ influx, as measured by ${ }^{45} \mathrm{Ca}^{2+}$ accumulation, and reduced somatic peak elevation in $\left[\mathrm{Ca}^{2+}\right]_{i}$, as measured by fura-2 video microscopy. These reductions are predictable given electrophysiological data indicating that acid $\mathrm{pH}$ moderately reduces current through AMPA-kainate receptor-gated channels (Christensen and Hida, 1990; Giffard et al., 1990a; Tang et al., 1990). As a hypothesis suitable for future testing, we think it likely that acid $\mathrm{pH}$-induced enhancement of toxicity reflects the marked impairment of $\left[\mathrm{Ca}^{2+}\right]_{i}$ normalization observed here after exposure to AMPA or kainate at acid $\mathrm{pH}$. This acid $\mathrm{pH}$-impaired recovery of $\left[\mathrm{Ca}^{2+}\right]_{\mathrm{i}}$ homeostasis could reflect increased release of $\mathrm{Ca}^{2+}$ from intracellular stores, reduced intracellular buffering, or reduced extrusion of $\mathrm{Ca}^{2+}$. For example, cells challenged with an acid load can be expected to try to restore $\mathrm{pH}$ homeostasis by activating the $\mathrm{Na}^{+}-\mathrm{H}^{+}$antiporter (Moody, 1981), thus increasing intracellular $\mathrm{Na}^{+}$and impairing $\mathrm{Ca}^{2+}$ extrusion via the $\mathrm{Na}^{+}{ }_{-}$ $\mathrm{Ca}^{2+}$ antiporter.

The selectivity of the $\mathrm{pH}$-dependent delayed normalization of $\left[\mathrm{Ca}^{2+}\right]_{\mathrm{i}}$, seen after AMPA-kainate receptor stimulation but not after comparable NMDA- or high $\mathrm{K}^{+}$-induced elevations in somatic $\left[\mathrm{Ca}^{2+}\right]_{\mathrm{i}}$, is yet another reminder that all pools of intracellular free $\mathrm{Ca}^{2+}$ are not equivalent (Lafon-Cazal et al., 1993; Tymianski et al., 1993). Specifically, a difference in the behavior of the $\left[\mathrm{Ca}^{2+}\right]_{\mathrm{i}}$ elevation induced by AMPA-kainate receptor stimulation, compared with that induced by NMDA receptor stimulation, might be linked to spatial differences in $\mathrm{Ca}^{2+}$ entry points. However, it is more difficult to explain the observed difference in $\mathrm{pH}$ sensitivity of $\left[\mathrm{Ca}^{2+}\right]_{\mathrm{i}}$ recovery after AMPAkainate receptor stimulation versus exposure to high $\mathrm{K}^{+}$, because most $\mathrm{Ca}^{2+}$ entry in both cases presumably occurs via the same voltage-gated $\mathrm{Ca}^{2+}$ channels (Fig. 5, delayed recovery noted in the majority of cells, even those with modest $\left[\mathrm{Ca}^{2+}\right]_{\mathrm{i}}$ responses). One possible explanation is that AMPA-kainate receptor activation might induce greater cellular $\mathrm{Na}^{+}$loading compared with that induced by high $\mathrm{K}^{+}$so that, as a result, the propensity of acid $\mathrm{pH}$ itself to induce cellular $\mathrm{Na}^{+}$-loading would have special impact on the $\mathrm{Na}^{+}-\mathrm{Ca}^{2+}$ antiporter (see above). It is unlikely that a $\mathrm{pH}$ paradox accounts for the observed $\mathrm{pH}$ enhancement of AMPA-kainate receptor-mediated neuronal death. Continued exposure to acid $\mathrm{pH}$, beyond the period of AMPA exposure, did not protect against the injury.

Cerebral tissue acidosis is a well established feature of ischemic brain tissue, which has long been considered an important factor in the pathogenesis of the resultant brain damage, especially glia death (Plum, 1983; Kraig et al., 1987; Siesjo, 1988; Giffard et al., 1990b; Nedergaard et al., 1991; Tombaugh and Sapolsky, 1993). However, moderate tissue acidosis may also provide some protective effects against neuronal injury by reducing NMDA receptor-mediated excitotoxicity. Both NMDA and AMPA-kainate receptor-mediated whole-cell currents in rat hippocampal neurons are attenuated by moderate extracellular acid- ity in the range of $6.2-7.2$, with the most dramatic effects produced on NMDA receptor-mediated currents (Tang et al., 1990). Similar inhibition of NMDA receptor-mediated currents has been observed on cultured cortical and cerebellar neurons (Giffard et al., 1990a; Traynelis and Cull-Candy, 1990). Reduction of extracellular $\mathrm{pH}$ below 6.5 reduces both glutamate neurotoxicity and oxygen-glucose deprivation-induced neuronal death in vitro (Giffard et al., 1990a; Tombaugh and Sapolsky, 1990; Kaku et al., 1993).

Present data thus raise the important possibility that the extracellular acidity that accompanies brain ischemia increases the prominence of AMPA-kainate receptor-mediated injury relative to NMDA receptor-mediated injury, not only by blocking the latter, but also by enhancing the former. Both the inhibition of NMDA receptor activation and exacerbation of AMPA-kainatemediated neuronal injury occur in the same clinically relevant acid $\mathrm{pH}$ range (6.2-7.4). We hypothesize that the toxic contribution of AMPA-kainate receptors might be most prominent during early stages of ischemia associated with acidic extracellular $\mathrm{pH}$, and that subsequently, the balance might shift back toward NMDA receptor-mediated injury as reperfusion occurs and extracellular $\mathrm{pH}$ returns to normal, and the acid $\mathrm{pH}$ inhibition of NMDA receptors is relieved. The acid $\mathrm{pH}$ shifts that accompany reversible focal and global ischemia generally normalize within 0.5-2 hr, with intracellular $\mathrm{pH}$ lagging behind extracellular $\mathrm{pH}$. However, normalization can be much slower in models of permanent focal ischemia (Siemkowicz and Hanson, 1981; Mabe et al., 1983; Smith et al., 1986; Von Hanweher et al., 1986; Silver and Erecinska, 1992; Tomlinson et al., 1993; Maruki et al., 1993; Dempsey et al., 1996). Our data suggest that brief periods of acid $\mathrm{pH}$ exposure, compatible with the $\mathrm{pH}$ changes observed in ischemia models, may importantly potentiate AMPA-kainate receptor-mediated neuronal death. This idea might have implications for the timing and selection of drug treatment in settings associated with prolonged tissue ischemia and acidosis such as stroke, status epilepticus, trauma, and subarachnoid hemorrhage (Becker, 1985; Siesjo and Wieloch, 1986; Siesjo, 1988; Brooke et al., 1994). The foregoing consideration is independent of the additional possibility that certain neuronal subpopulations expressing $\mathrm{Ca}^{2+}$-permeable AMPA or kainate receptors, e.g., Purkinje cells (Brorson et al., 1994) or NADPH-diaphorase-nitric oxide synthase-containing neurons (Koh and Choi, 1988; Weiss et al., 1994), may exhibit heightened baseline vulnerability to AMPA-kainate receptor-mediated injury. In addition, the possibility has been raised that sublethal ischemic insults may selectively depress the expression of the $\mathrm{Ca}^{2+}$-gatekeeper AMPA receptor subunit, gluR-B/gluR-2 (Hollman et al., 1991; Verdoorn et al., 1991) relative to other AMPA receptor subunits, perhaps enhancing AMPA-kainate receptor-mediated $\mathrm{Ca}^{2+}$ influx and death (Pellegrini-Giampietro et al., 1992; Gorter et al., 1997; Ying et al., 1996). Finally, we have recently found that oligodendrocytes maintained for $>3$ weeks in vitro develop prominent vulnerability to AMPA-kainate receptor-mediated excitotoxic death, comparable to that of neurons (McDonald et al., 1996b, 1998). The ability of AMPA-kainate antagonists to reduce brain damage in animal models of brain ischemia may reflect contributions from some or all of these factors.

\section{REFERENCES}

Albers GW, Goldberg MP, Choi DW (1992) Do NMDA antagonists prevent neuronal injury? Yes. Arch Neurol 49:418-420.

Balchen T, Diemer NH (1992) The AMPA antagonist, NBQX, protects 
against ischemia-induced loss of cerebellar Purkinje cells. NeuroReport 3:785-788.

Becker DP (1985) Brain acidosis in head injury: a clinical trial. In: Central nervous system trauma status report 1985 (Becker DP, Povlishock JT, eds), pp 229-242. Richmond: Byrd.

Brooke NSR, Ouwerkerk R, Adams CBT, Radda GK, Ledingham JGG, Rajagopalan B (1994) Phosphorus-31 magnetic resonance spectra reveal prolonged intracellular acidosis in the brain following subarachnoid hemorrhage. Proc Natl Acad Sci 91:1903-1907.

Brorson JR, Manzolillo PA, Miller RJ (1994) $\mathrm{Ca}^{2+}$ entry via AMPA/KA receptors and excitotoxicity in cultured cerebellar Purkinje cells. J Neurosci 14:187-197.

Bruno VMG, Goldberg MP, Dugan LL, Giffard RG, Choi DW (1994) Neuroprotective effect of hypothermia in cortical cultures exposed to oxygen-glucose deprivation or excitatory amino acids. J Neurochem 63:1398-1406.

Buchan AM, Xue D, Haung ZG, Smith KH, Lesiuk H (1991a) Delayed AMPA receptor blockade reduces cerebral infarction induced by focal ischemia. NeuroReport 2:473-476.

Buchan AM, Li H, Pulsinelli WA (1991b) The $N$-methyl-D-aspartate antagonist, MK-801, fails to protect against neuronal damage caused by transient, severe forebrain ischemia in adult rats. $\mathrm{J}$ Neurosci 11:1049-1056.

Choi DW (1987) Ionic dependence of glutamate neurotoxicity in cortical cell culture. J Neurosci 7:369-379.

Choi DW (1988) Glutamate neurotoxicity and diseases of the nervous system. Neuron 1:623-634.

Choi DW (1992) Excitotoxic cell death. J Neurobiol 23:1261-1276.

Christensen BN, Hida E (1990) Protonation of histidine groups inhibits gating of the quisqualate/kainate channel protein in isolated catfish cone horizontal cells. Neuron 5:471-478.

Csernansky CA, Canzoniero LMT, Sensi SL, Yu SP, Choi DW (1994) Delayed application of aurintricarboxylic acid reduces glutamateinduced cortical neuronal injury. J Neurosci 38:101-108.

David JC, Yamada KA, Bagwe MR, Goldberg MP (1996) AMPA receptor activation is rapidly toxic to cortical astrocytes when desensitization is blocked. J Neurosci 16:200-209.

Dawson RMC, Elliot DC, Elliot WH, Jones KM (1986) Data of biochemical research, 3rd ed, p 433. Oxford: Oxford Science Publications.

Dempsey RJ, Baskaya MK, Combs DJ, Donaldson D, Rao AM, Prasad MR (1996) Delayed hyperglycemia and intracellular acidosis during focal cerebral ischemia in cats. Acta Neurochir 138:745-751.

Giffard RG, Monyer H, Christine CW, Choi DW (1990a) Acidosis reduces NMDA receptor activation, glutamate neurotoxicity, and oxygen-glucose deprivation neuronal injury in cortical cultures. Brain Res 506:339-342.

Giffard RG, Monyer H, Choi DW (1990b) Selective vulnerability of cultured cortical glia to injury by extracellular acidosis. Brain Res 530:138-141.

Gill R (1994) The pharmacology of 181-amino-3-hydroxy-5-methyl-4isoxazole propionate (AMPA)/kainate antagonists and their role in cerebral ischemia. Cerebrovasc Brain Metab Rev 6:225-256.

Goldberg MP, Choi DW (1993) Combined oxygen and glucose deprivation in cortical cell culture: calcium-dependent and calciumindependent mechanisms of neuronal injury. J Neurosci 13:3510-3524.

Gorter JA, Petrozzino JJ, Aronica EM, Rosenbaum DM, Opitz T, Bennett MVL, Connor JA, Zukin RS (1997) Global ischemia induces down regulation of Glur2 mRNA and increases AMPA receptormediated $\mathrm{Ca}^{2+}$ influx in hippocampal CA1 neurons of gerbil. J Neurosci 17:6179-6188.

Grynkiewicz G, Poenie M, Tsien R (1985) A new generation of $\mathrm{Ca}^{2+}$ indicators with greatly improved fluorescence properties. J Biol Chem 260:3440-3450.

Hartley DM, Kurth MC, Bjerkness L, Weiss JH, Choi DW (1993) Glutamate receptor-induced ${ }^{45} \mathrm{Ca}^{2+}$ accumulation in cortical cell culture correlates with subsequent neuronal degeneration. J Neurosci 13:1993-2000.

Hollman M, Hartley M, Heinemann S (1991) $\mathrm{Ca}^{2+}$ permeability of KA-AMPA-gated glutamate receptor channels depends on subunit composition. Science 252:851-853.

Kaku DA, Goldberg MP, Choi, DW (1991) Antagonism of non-NMDA receptors augments the neuroprotective effect of NMDA receptor blockade in cortical cultures subjected to prolonged deprivation of oxygen and glucose. Brain Res 554:344-347.
Kaku DA, Giffard RG, Choi DW (1993) Neuroprotective effects of glutamate antagonists and extracellular acidity. Science 260:1516-1518.

Koh J, Choi DW (1987) Quantitative determination of glutamatemediated cortical neuronal injury in cell culture by lactate dehydrogenase efflux assay. J Neurosci Methods 20:83-90.

Koh JY, Choi DW (1988) Vulnerability of cultural cortical neurons to damage by excitotoxins: differential susceptibility of neurons containing NADPH-diaphorase. J Neurosci 8:2153-2163.

Koh JY, Choi DW (1991) Selective blockade of non-NMDA receptors does not block rapidly triggered glutamate-induced neuronal death. Brain Res 548:318-321.

Koh JY, Goldberg MP, Hartley DM, Choi DW (1990) Non-NMDA receptor-mediated neurotoxicity in cortical culture. J Neurosci 10:693-705.

Kraig RP, Petito CK, Plum F, Pulsinelli WA (1987) Hydrogen ions kill brain at concentrations reached in ischemia. J Cereb Blood Flow Metab 7:379-386.

Lafon-Cazal M, Pietri S, Culcasi, M, Bockaert J (1993) NMDAdependent superoxide production and neurotoxicity. Nature 364:535-537.

Le-Peillet E, Arvin B, Moncada C, Meldrum BS (1992) The nonNMDA antagonists, NBQX and GYKI 52466, protect against cortical and striatal cell loss following transient global ischemia in the rat. Brain Res 571:115-120.

MacDermott AB, Mayer ML, Westbrook GL, Smith SJ, Barker JL (1986) NMDA receptor activation increases cytoplasmic calcium concentration in cultured spinal cord neurons. Nature 321:519-522.

May PC, Robinson PM (1993) Cyclothiazide treatment unmasks AMPA excitotoxicity in rat primary hippocampal cultures. J Neurochem 60:1171-1174.

McDonald JW, Bhattacharyya T, Sensi SL, Lobner D, Ying HS, Choi DW (1996a) Extracellular acidic pH exacerbates AMPA receptormediated neuronal injury. Ann Neurol 46:A468.

McDonald JW, Althomsons SP, Hyrc KL, Goldberg MP, Choi DW (1996b) Oligodendrocytes are highly susceptible to AMPA/kainate receptor- and hypoxia-induced death. J Neurotrauma 13:599.

McDonald JW, Althomsons SP, Hyrc KL, Choi DW and Goldberg MP (1998) Oligodendrocytes are highly vulnerable to AMPA/kainate receptor-mediated excitotoxicity. Nature Med 4:291-297.

Meldrum B (1985) Possible therapeutic applications of antagonists of excitatory amino acid neurotransmitters. Clin Sci 68:113-122.

Moody Jr WJ (1981) The ionic mechanism of intracellular $\mathrm{pH}$ regulation in crayfish neurones. J Physiol (Lond) 316:293-308.

Moudy AM, Yamada KA, Rothman SM (1994) Rapid desensitization determines the pharmacology of glutamate neurotoxicity. Neuropharmacology 33:953-962.

Nedergaard M, Goldman SA, Desai S, Pulsinelli WA (1991) Acidinduced death in neurons and glia. J Neurosci 11:2489-2497.

Nemoto EM, Frinak S (1981) Brain tissue pH after global brain ischemia and barbituate loading in rats. Stroke 12:77-82.

Nurse S, Corbett D (1996) Neuroprotection after several days of mild, drug-induced hypothermia. J Cereb Blood Flow Metab 16:474-480.

Patneau DK, Vyklicky Jr L, Mayer ML (1993) Hippocampal neurons exhibit cyclothiazide-sensitive rapidly desensitizing responses to kainate. J Neurosci 13:3496-3509.

Pellegrini-Giampietro DE, Zukin RS, Bennett MV, Cho S, Pulsinelli WA (1992) Switch in glutamate receptor subunit gene expression in CA1 subfield of hippocampus following global ischemia in rats. Proc Natl Acad Sci USA 89:10499-10503.

Plum F (1983) What causes infarction in ischemia brain? Neurology 33:222-233.

Rose K, Goldberg MP, Choi DW (1992) Cytotoxicity in murine cortical cell culture. In: In vitro biological methods, methods in toxicology (Tyson CA, Frazier JM, eds), pp 46-60. San Diego: Academic.

Rothman SM, Olney JW (1987) Excitotoxicity and the NMDA receptor. Trends Neurosci 10:299-302.

Sheardown MJ, Nielsen EO, Hansen AJ, Jacobsen P, Honore, T (1990) 2,3-Dihydroxy-6-nitro-7-sulfamoylbenzo(F)quinoxaline: a neuroprotectant for cerebral ischemia. Science 247:571-574.

Sheardown MJ, Suzdak PD, Nordholm L (1993) AMPA, but not NMDA, receptor antagonism is neuroprotective in gerbil global ischemia, even when delayed 24 hr. Eur J Pharmacol 236:347-353.

Siemkowicz E, Hansen AJ (1981) Brain extracellular ion composition and EEG activity following $10 \mathrm{~min}$ ischemia in normo- and hyperglycemic rats. Stroke 12:236-240. 
Siesjo BK and Wieloch T (1986) Epileptic brain damage: pathophysiology and neurochemical pathology. Adv Neurol 44:813-847.

Siesjo BK (1988) Acidosis and ischemic brain damage. Neurochem Pathol 9:31-88.

Simon RP, Swan JH, Griffiths T, Meldrum BS (1984) Blockade of $N$-methyl-D-aspartate receptors may protect against ischemic damage in brain. Science 226:850-852.

Smith SE, Meldrum BS (1992) Cerebroprotective effect of a non- $N$ methyl-D-aspartate antagonist, GYKI 52466, after focal ischemia in the rat. Stroke 23:861-864.

Tang CM, Dichter M, Morad, M (1990) Modulation of the $N$-methyl-Daspartate channel by extracellular $\mathrm{H}^{+}$. Proc Natl Acad Sci USA 87:6445-6449.

Tombaugh GC, Sapolsky RM (1990) Mild acidosis protects hippocampal neurons from injury induced by oxygen and glucose deprivation. Brain Res 506:343-345.

Tombaugh GC, Sapolsky RM (1993) Evolving concepts about the role of acidosis in ischemic neuropathology. J Neurochem 61:793-803.

Traynelis SF, Cull-Candy SG (1990) Proton inhibition of $N$-methyl-Daspartate receptors in cerebellar neurons. Nature 345:347-350.
Tymianski M, Charlton MP, Carlen PL, Tator CH (1993) Source specificity of early calcium neurotoxicity in cultured embryonic spinal neurons. J Neurosci 13:2085-2104.

Verdoorn TA, Burnashev N, Monyer H, Seeburg PH, Sakmann B (1991) Structural determinants of ion flow through recombinant glutamate receptor channels. Science 252:1715-1718.

Weiss JH, Turetsky DM, Wilke G, Choi DW (1994) AMPA/kainate receptor-mediated damage to NADPH-diaphorase containing neurons is $\mathrm{Ca}^{2+}$ dependent. Neurosci Lett 167:93-96.

Yamada KA, Rothman SM (1992) Diazoxide blocks glutamate desensitization and prolongs excitatory postsynaptic currents in rat hippocampal neurons. J Physiol (Lond) 458:409-423.

Ying HS, Weishaupt J, Grabb M, Canzoniero SMT, Sensi SL, Monyer H, Choi DW (1996) AMPA receptor expression in cultured rat hippocampal neurons following sublethal oxygen-glucose deprivation. Soc Neurosci Abstr 22:597.

Zorumski C, Yamada KA, Price MT, Olney JW (1993) A benzodiazepine recognition site associated with the non-NMDA glutamate receptor. Neuron 10:61-67. 